\title{
Stone Statues and Hollow Statues: The Search for Authenticity in Sinhala Nationalist Discourse
}

\begin{abstract}
Authenticity is an abiding concern visible in much of nationalist discourse, especially anti-colonial and postcolonial nationalisms. While modernist theorists of nationalism such as Hobsbawm, Gellner, Kedourie and Anderson tend to highlight the inauthenticity of nationalism - highlighting its modern provenance as opposed to its self-professed antiquity postcolonial theorists of nationalism such as Chatterjee have been more sensitive to the conditions of its production. The possibility of (re)discovering, (re)animating and deploying authenticity becomes a crucial element in the cultural imaginary of anti-colonial nationalism. While it is important to contest and deconstruct such discourses of authenticity, it is equally, if not more important to be attuned to the contextual factors that shape the desire for authenticity. This paper attempts to trace the discourse of authenticity as it manifests itself in the writing of Anagarika Dharmapala and S.W.R.D. Bandaranaike, who can be considered 'father figures' in the Sinhala nationalist imagination and in turn how the writing of Gunadasa Amarasekara perpetuates this discourse while selectively appropriating the legacies of the father figures.
\end{abstract}

Keywords: Sri Lanka, Decolonization, Authenticity, Buddhism, Sinhala nationalism, History, Sinhala literature 


\section{Introduction}

A youthful S.W.R D. Bandaranaike freshly returned from Oxford addressed a crowd near his hometown in Gampaha and apologised for speaking in English:

The first thing I must do is to apologise to you for speaking to you in English. Owing to my long absence from my country, I am not sufficiently fluent in Sinhalese to be able to address you in Sinhalese at length. That is a fault that can be easily remedied. What is more important is that my heart should be sound. And I can assure you that my heart is Sinhalese to the core.

(Bandaranaike "Speeches and Writings": 83)

One may dismiss this as mere political posturing given that these are words uttered by a politician whose career was marked by many contradictions, leading James Manor the author of Bandaranaike's single political biography to call him an "expedient utopian". But rather than question the motives or intent of a politician, an always risky business, I quote the above because I believe it speaks to a number of themes central to the search for authenticity in modern Sinhala nationalist discourse. At one level is a belief that there is a transcendental and timeless Sinhala cultural essence. From the perspective of the anti-colonial or postcolonial nationalist, this is a crucial belief and one that sustains the possibility of cultural and national autonomy. But accompanying this belief is also a crisis of defining and locating authenticity. For each of the three nationalist figures discussed in this paper, authenticity is not simply a readily available object 'out there' as it were to be simply retrieved. Instead they have to engage in an exhaustive attempt to reconstruct and reconstitute the authentic so that it becomes available for their respective nationalist projects. But what is evident in this process is the elusive nature of authenticity itself.

Many modernist studies of nationalism have critiqued this 'constructed' and 'artificial' nature of authenticity in nationalist discourse. Ernest Gellner's statement that "It is nationalism which engenders nations, and not the other way round" and the title of Hobsbawm and Ranger's The Invention of Tradition are just two examples of a long and distinguished tradition of scholarship which has treated nationalist claims to tradition with a great deal of scepticism and even derision. Some of this impatience with nationalism can be traced to the work of scholars like Elie Kedourie, who writing in the aftermath of the destructive legacies of German National Socialism, see nationalism as a thoroughly modern phenomenon that is associated with statist institutional practices though it often appears with a romantic gloss. One common feature of Kedourie's, Gellner's and the later work of Benedict Anderson is that they see modern nationalism as a product of the transition from an agrarian economy to an industrial one and the kind of Weberian bureaucratic rationalization that accompanies this shift in mode of production. Anderson's highly influential innovation was to argue that a popular or populist nationalist consciousness becomes possible only with, what he terms, "print capitalism", which allows for the simultaneous imagination and invocation of a national "imagined community" ("Imagined Communities").

The work of Partha Chattrejee, possibly the most significant post-colonial scholar of nationalism, invites us to look at nationalism differently, especially in the post-colonial global south ("Nationalist Thought", "The Nation and its Fragments"). Using Indian nationalism, and especially the innovations of the Bengali nationalist elite, Chatterjee explores why, at least in an anti- and to some extent a post-colonial context notions of tradition and authenticity become politically enabling. Chatterjee posits that for Indian nationalism the possibility of imagining an authentic inner cultural core within the familial or private domain, as opposed to the public sphere, which was thoroughly colonized and dominated by colonialism, was a strategically essential move. Given the fact that Indian nationalists lacked 
either the economic or military ability to successfully challenge British imperialism in the public sphere, Chatterjee argues that culture-and especially the notion of an authentic inner-core, untainted by colonial contact and its claims to omnipotence-was a crucially enabling site from which Indian nationalist resistance emerged. Chatterjee also shows, however, that this nationalist project while successful in resolving the 'problematic' of anticolonial nationalism - that is, to challenge the notion that the West is superior to the East by ultimately wresting power from the colonizer-fails at the level of the 'thematic'. The 'thematic,' as Chatterjee proposes it, is the problem of looking at the world through Manichean binaries such as the East and the West. He critiques the essentialism of such a perspective and the way it traps the nationalist imagination in categories of self-other, which translates into politics of exclusion and inclusion in the post-colonial nation state. The importance of Chatterjee's work, however, is that, while being cautious of essentialist nationalist claims, it allows for a critical reflection on the conditions under which nationalist discourses of authenticity are produced (Nationalist Thought).

This desire for the authentic can also be located within what Aamir Mufti and Ranajit Guha call a culture of mourning that often accompanies anti-colonial nationalist thinking. It is a sense of loss and pain emerging from the colonial encounter. As Guha says, "Whenever I hear the phrase colonial India, it hurts me. It hurts like an injury that has healed and yet has retained somehow a trace of the original pain..." (85, emphasis original). But it is also a pain which nationalism, as Guha with wry cynicism points out, appropriates to create "a cult of mourning" (98). It is this culture of mourning that Mufti argues generates an "aura of authenticity" within which the post-colonial present is seen as inauthentic - a kind of fallen state where the authentic past haunts the nationalist imagination. This is, however, not merely an expression of populist nationalism yearning for a romantic lost past but a conceptual orientation which seeks a space that is outside the putatively "western". It is in essence what Chartterjee meant by the thematic of anti-colonial thinking: a Manichean worldview in which the East and West figure as essentially different and divided entities. ${ }^{1}$

\section{Dharmapala, Sinhala Identity, Buddhism and the World}

Dharmapala is not discussed extensively here since he is a relatively familiar figure. It is important to note, however, that Dharmapala's currency in contemporary academic discourse and in the popular imagination as a stereotypical Sinhala Buddhist nationalist is a retrospective appropriation of the man shaped by contemporary nationalist concerns. To speak of Sinhala nationalism or Sinhala Buddhist nationalism in the mid nineteenth or early twentieth century can be misleading as critics like Michael Roberts have pointed out (1010). As Roberts puts it "Anagarika Dharmapala was occupying the wings of a 'cathedral' where the nave that fronted up to the 'British' altar was occupied in the period 1880-1930 by personnel committed to - no doubt in varying measures to-Ceylonese nationalism" (1012). Thus figures like Dharmapala at one moment could occupy a position which appears exclusivist yet at another appear more inclusive. This is largely reflective of the uncertain grounds from which Dharmapala's proto-nationalist imagination emerges - what constitutes the Sri Lankan nation or its cultural imaginary is not something clearly defined in this historical context. ${ }^{2}$ This is in contrast to post-independence Sri Lanka by which time

\footnotetext{
${ }^{1}$ It is a deep structure of thought that can be traced even in academic production as diverse as the work of Talal Asad and Ashis Nandy. In both Asad's and Nandy's work there is a sense of an incommensurable East-West divide that is unbridgeable. See Bangstad for a critique of the East-West dichotomy in Asad. See Mufti for a critique of Nandy. Also see Rambukwella for a critique of how the post-secular discourse which is becoming a major force in the American academia operates on this East-West binary.

2 It is at a much later stage in history, possibly post-1956 that we are comfortably able to speak of Sinhala nationalism as it is understood today. For instance, in the 1912 Legislative Council elections when there was a contest between a Karava Sinhalese candidate and a Tamil Vellala candidate for the seat of the "educated Ceylonese Representative" the Goyigama Sinhalese backed the Tamil Vellala candidate, thus suggesting that caste, at this point, superseded ethnicity in national politics.
} 
representative democratic practices and a host of other institutional and cultural practices had crystallized a much clearer sense of Sinhala and Tamil nationalist ideology. The institutionalization of ethnic identity played a major role in this process with ethnicity being accorded an institutional value and function it largely lacked in early nineteenth century Sri Lanka (see for instance, Nissan and Stirrarat).

This ambivalence is evident for instance in the article "A Message to the Young Men of Ceylon" published in 1922. The title appears to address a Ceylonese identity rather than a Sinhala or Buddhist one but in the opening paragraph there is reference to Dutugemunu unifying the nation and a historical narrative that would today be seen as specifically Sinhala and Buddhist. However, such invocations of Sri Lanka's historical grandeur were common at the time and others like James de Alwis (a Sinhala Christian), decades before Dharmapala, had looked to a similar past for inspiration in expressing quasi-nationalist sentiments. ${ }^{3}$ Later in the article Dharmapala speaks of how religion is no bar to patriotism and the call for national revival is extended to Sinhala Christians. ${ }^{4}$ However, despite the appeal for Sinhala Christian and Buddhist unity in a common cause, Sinhala identity for Dharmapala remains primarily a Buddhist one. While at times he includes Christian Sinhalese as part of the Sinhala community, they are at best seen as a fallen subset that requires pity and empathy: "A small portion of the Sinhalese nation, under the compulsion of the invading freebooters and pirates in the 16th century of the Christian era adopted the religion of the Roman Pope" (Guruge: 502). The semantic ambivalence in this article which invokes Ceylon in the title, references the Dutugemunu narrative, and then positions Sinhala Christians in ambiguous terrain but also attempts to bring them within the patriotic fold is indicative of the uncertain nature of the proto-nationalist discourse Dharmpala represents. One may also note here that the name of the country "Ceylon" had a multicultural resonance, at least within an anglicized elite community, that "Sri Lanka" the country's contemporary name lacks. "Sri Lanka" emerges from the politics of decolonization represented by the first republican constitution of 1972, which signified a complete break from the British Empire. It is also a name that is associated with rising Sinhala and Buddhist nationalist consciousness because it was the 1972 constitution that included an explicit clause giving Buddhism "a foremost place" among religions in the country.

One discernible constant in Dharmapala's writing is Buddhism. It is a discourse that connects Sri Lanka with the narrative of a glorious past while also placing Sri Lanka simultaneously within the world context. Acutely sensitive to the lack of material and technological development in his own culture Dharmapala's writing constantly associates Buddhism with modernity, rationality and progress with the implication that Sri Lankan culture though technologically backward is culturally advanced. In contrast, Christianity (his most persistent target for criticism are missionaries) is jaded, non-modern and irrational - which was a critique available to Dharmapala through the ongoing rationalist, western interpretation of Buddhism at the time which coincided with the scientific/secularist critique of Christianity in Europe. Dharmapala could express admiration for industrial Europe but at the same time separate it from European culture which he equates with Christianity - a religion he saw as non-modern and regressive. The possibilities for this critique were historically available to Dharmapala. A strong fin-de-siècle rationalist-scientific discourse was challenging the place of Christianity in the public sphere while Buddhism, at the same time, was being constructed as rational and scientific due to the work of Orientalist scholars within the larger discourse of the Oriental Renaissance (Lopez: 6-10; McMahan).

\footnotetext{
${ }^{3}$ By Dharmapala's time however the Buddhist revival had gathered force and references to Dutugemeunu and Sri Lanka's Buddhist past could potentially have a different resonance.

${ }^{4}$ But while an attempt is made to transcend divisions within Sinhala society, there is no conscious attempt to include other communities.
} 
The work of Theosophists also contributed to giving Buddhism and other eastern religions an avant-garde position in relation to Christianity though Theosophy's emphasis was more mystical than scientific (Owen: 6-8). The Buddhist past of the country thus provided it with a classical genealogy and a high level of civilisational achievement while in the present it placed Sri Lanka within the currents of what he saw as the rational, scientific tenor of the times. From one of his earliest international speeches at the World Parliament of Religions held in Chicago in 1893, "The World's Debt to Buddha" (Guruge: 3-22), to articles he wrote in the late 1920s the idea that Buddhism has a vital role to play in the modern world is an abiding theme.

Dharmapala, like most educated commentators of the time, also subscribed to what John Rogers has described as a three-stage model of Sri Lankan history which moves from a classical age (Anuradhapura and Polonnaruwa kingdoms), through a dark middle passage (South Indian invasions and the so-called "drift to the South" of Sinhala kingdoms), to the contemporary colonial moment. But he interrupts the teleology of this trajectory by substituting a colonial-western derived modernity for one which selectively appropriates the past. Dharmapala believed in the possibility of resurrecting the glories of the Sinhala past within a modern/technological framework. To Dharmapala industrial/material aspects are not something alien to Sinhala life because he believed the Sinhalese had achieved technical sophistication in the past within a Buddhist civilizational frame while, in his own time, Japan (a country he had visited and greatly admired) presented a model of material development that was in harmony with tradition.

Europe is progressive. Her religion is kept in the background for one day in the week, and for six days her peoples are following the dictates of modern science....

The Sinhalese, Bengalese, Madrasees, Bombayites, Panjabees, Burmese, Chinese and Koreans that go to Europe and America to study in the colleges [sic] law and medicine return after several years thoroughly Europeanised. The Japanese are the only practical people who have sent their sons to learn the technical sciences. They are reaping the fruits of practical wisdom.

(Guruge: 717-18)

The village, which is an important index of authenticity in Bandarnaike and Amarasekara, occupies an ambiguous position in Dharmapala's thinking. Contrasted with the glories of the past and the ideal modernity he conceives, Sinhala villagers represent a degenerate community that needs reformation. The village is not seen as the repository of an authentic Sinhala identity but a space which needs reformation. Attempting to defend the village as the repository of a transcendental Sinhala essence, as we shall see in Amarasekara's writing, is a non-issue for Dharmapala. For instance, Dharmapala published a pamphlet entitled Facts people should know (Denagatha yuthu karunu) in which he provides a long list of Victorian-inspired etiquette-related practices that he advocates that Sinhala people should adopt. Obeysekere argues these are clearly addressed to Sinhala people who have migrated from villages to urban areas with the intention of their gentrification. The main emphasis in Dharmapala is on making Sinhala society (or Sri Lanka in general) coeval with the world rather than on a romantic notion of village life and Buddhism plays a crucial role in this process. Buddhism is the single most important index of authenticity for Dharmapala because the Sinhalese are at their most authentic when they are Buddhist but it is also Buddhism that authenticates the nation in the present by giving it a unique place in the world. 


\section{S.W.R.D. Bandaranaike: In Search of Political and Individual Authenticity}

S.W.R.D. Bandaranaike can be understood as man who searched for authenticity in both his public and private lives. Born to an anglicized, Christian family and almost exclusively educated in English he sought to reinvent himself as the leader of a decolonizing nation. Although his turn to the Sinhala language and Buddhism are generally understood as a political move to indigenize himself, it was also one informed by an oedipal sensitivity to the cultural and political legacies of his familial heritage as represented by his father (Manor). Bandaranaike's father was an authoritarian and distant father figure and one who consciously cultivated an anglicized image-an image that Bandaranaike who modeled himself as a decolonizing leader sought to disavow. But, in Manor's text (and others), there is little attempt to explore how this discourse of authenticity is generated and the various influences that shape it. The following short anecdotal story, published by Bandaranaike in the Island Review of 1926, captures some crucial elements of Bandaranaike's relationship to the discourse of authenticity. The story foregrounds the shift in Bandaranaike towards a conception of the indigenous while simultaneously revealing his distance from it. The attempt to bridge this distance appears in the form of elite politico-cultural discourse that attempts to speak on behalf of the subaltern and thereby the nation. ${ }^{5}$

That night, John stood on the verandah of the Queen's Hotel, watching the procession go by, the temple officials in their gorgeous robes...the long row of elephants bright with their gaudy trappings, with the finest of them all in the centre, bearing the sacred relic-all moving slowly, with a tantalising slowness and swaying from side to side as they went; the dancers with their grotesque masks and still more grotesque movements; the weird, unearthly music, the pipes, the drums - all combined to create in John's mind a feeling of unreality; it all seemed to him a dream, the figment of a disordered mind. He looked on, and, as he looked, the barriers of time seemed to roll away, and he seemed to be transported to an age long past, to a time of his country's glory and its power, when the same procession passed along the same streets.... He looked nearer, and saw the crowds along the lake bund-the older men and women tired and worn, the young men and girls watching with parted lips and shining eyes, while, occasionally, the crying of a child mingled with the music of the pipes and then something seems to snap in John: a wild, throbbing love surged through him. "My country, my people," he murmured, "how wonderful it all is, and I never knew it till today". His fingers fumbled at his shirt front and collar; in an instant he would have torn away those highly respectable garments of civilisation and mingled with that surging mass - his people. Just then he heard the voice of one of his friends, "John, you fat-head, come and make up a four at bridge". The reaction made him stagger and reel like a drunken man for an instant: then he steadied himself and went. "Good gracious!" said someone, "What have you done to your shirt, John? It is all crumpled up."

"My dear fellow," said John, "I never could bear a starched shirt front. Don't you think a crumpled one looks jollier somehow? Like a face creased in smiles. Two no trumps is my call!"

("Speeches and Writings": 465-6)

\footnotetext{
${ }^{5}$ While I acknowledge the need to be cautious in attempting a biographical reading of a piece of fiction, I am supported in such an approach by the note from the editors of the original publication who say that they believe Bandaranaike is writing about himself here as well as a general trend towards connecting with the "local" that is visible in Bandaranaike's corpus of writing.
} 
The story begins with John, an obviously westernized individual, observing the Perahera from a vantage of privilege which sets him apart from both the action and the mass of people observing it, which also renders the scene below exotic to John. But this sense of being witness to a nightmare of the other is quickly subsumed; the modern, westernised self is shown to be easily displaceable. John is transported into the past so that instead of the difference between now and then, what emerges is the space of what Anderson calls "homogenous empty time". The self merges with the nation in this collapsing of temporal distance. The "time of his country's glory and its power" or a historical consciousness that John assumes is shared by the crowd witnessing the procession enables identification between the self and the collective. In this collapsing of temporal distance, something that might have been an abstract historical consciousness gains a living, breathing presence and John acquires a new appreciation for the past of his country. What is visible here is the simultaneity of the experience. John and the crowd are witnessing the same event and from John's perspective, at least, they share a common historical consciousness. Thus, though the past is the ostensible common ground, it is a past that has already been drawn into a modern temporality. Like the act of reading the morning newspaper that Anderson cites, the spectacle of the procession allows the nation to be enacted in a simultaneous temporal framework. But an important caveat is necessary here-what we get is John's perspective only, not that of the crowd.

Within John's movement from present to past and back a hazy sense of national leadership also seems to emerge. As he begins to move back to the present, John sees the people and begins to identify with them. Though it remains unclear in the passage, there seems to be some interplay and contrast between the past magnificence of the country and its present. The old men and women are tired and worn, but there is a new generation of young hopefuls looking on. Both groups are potential inheritors of the past heritage John glimpses-possibly anticipating or hoping for the actualisation of the past glory in the present. It is possibly with this realisation that an almost animistic desire takes over John to strip away the external markers of his westernisation and merge with the crowd. But before he can do so, a call from the familiar space of the Bridge table pulls him back to reality. The story thus charts a process of radical dislocation, resulting in a form of illumination and return -in some ways mimicking a speeded-up version of a Bildungsroman. However, John never really joins the crowd. Even if there is some emotional connection established, the physical movement never reaches denouement. Similar to a Bildungsroman, there is a sense of social integration at the end. But the invitation to the reader is of course to see John as a changed man. He is now someone with a keener appreciation of the history of his country and possibly with a keener sense of duty towards his people.

Significantly, though, John's identification with the crowd happens via the mediation of history. It is the realisation of a common historical legacy that allows John to bridge the socio-cultural gap between himself and the people. It is important to note that the historical consciousness central to John's realisation of the past greatness of his country might not be shared by the common people. Such a historical consciousness is usually associated with elite and bourgeois intellectual discourse (as is evident in Dharmapala's writing). Nationalism often deploys such a common history in an attempt to draw a large cross-section of people into its project but simultaneously holds them at a distance because they have first to be educated and reformed before they can embody the national essence. Thus the common people represent an idealised but also paradoxical image - they are thought to be an embodiment of the authentic ideals of the nation but at the same time have to be moulded into this image of authenticity. ${ }^{6}$ Bandaranaike's writing on Buddhism and the village record

\footnotetext{
${ }^{6}$ Partha Chatterjee discusses a similar process in The Nation and its Fragments (1986) in relation to Indian anti-colonial nationalist thinking. Chatterjee describes how Gandhian thought attempted to extend an essentially bourgeoisie notion of Indian identity to the peasantry.
} 
traces of a dynamic similar to the one experienced by the fictional John. There is an involuntary, compulsive movement towards indigenity but it is a movement that never really reaches its destination. A preconceived image of the authentic nation and its ideals directs the movement, but there is also belief that this image is already embodied in the people. If, at times, the people do not actualise or act according to this ideal vision, nationalism's task becomes the inscription of the values of the ideal upon the people, the body of the nation.

The place of village and Buddhism in Bandaranaike's imagination is not discussed in detail here but following are the broad contours of how Bandaranaike approaches these two indices of authenticity. The village is seen as a microcosmic representation of the nation's fundamental socio-economic values. But as in most Sri Lankan post-independence political discourse, this is from a tutelary or custodial perspective. The village unit is associated with paddy cultivation which links it unequivocally with the grand narrative of Sri Lanka's past hydraulic civilization. As Mick Moore (3, 117-171, 119-120) argues, this discourse has powerfully shaped economic and development policy in post-independence Sri Lanka, with negative consequences to the rural economy. Moore argues that by promoting paddy cultivation, the cultivation of cash crops and agricultural practices that could have raised rural incomes were sidelined. But this is also at a larger level connected to a decolonizing discourse operating at the regional and international level where a return to 'local' values, local economy, etc., is emphasized. 7 This imaginary of the village cannot therefore be understood in isolation from larger regional and international political trends and once again highlights that imaginaries of authenticity are products of specific socio-historical and political conjunctures.

In Bandaranaike's writing on Buddhism he represents it as a rational discourse which is intrinsically more attractive to his sceptical rationalist outlook than the Christianity of his childhood. While not articulated with the same force as Dharmapala's, Bandaranaike too presents Buddhism as a discourse that resonates with modernity. In an article published in the early 1930s entitled "Why I Became a Buddhist" ("Speeches and Writings": 287-96), partly as a response to the criticism that his conversion was politically motivated, he provides a narrative of his early dissatisfaction with Christianity which hardened into its complete rejection at Oxford with the influence of such writers and thinkers as George Bernard Shaw, James Frazer and Bertrand Russell. In this article and several others in which Bandaranaike refers to Buddhism and religion in general, the mytho-historical narrative so central to Dharmapala's imagination is largely absent while he presents Buddhism as a universal discourse rather than a particular cultural legacy of the Sinhalese.

However, in a speech broadcast on radio in 1953 to mark Vesak, a more ambiguous narrative emerges where Bandaranaike oscillates between claiming Buddhism as a specifically Sinhala cultural legacy and something more universal. The speech opens with an invocation of the Vijaya myth and the Buddha's consecration of Lanka but then moves on to talk about Buddhism as a rational discourse in a much more generic sense. However, at the end of the speech, he re-invokes the mytho-historic narrative of the land, religion and race triad central to modern Sinhala nationalism, but only to argue that a return to the doctrinal basis of Buddhism (for which he has been arguing throughout the speech in a reformist tone) will in fact make people "...rise above the bounds of nationality, to embrace all life itself and sincerely to say, and say most fittingly on this day of all days, those simple and oft-repeated, but magnificent words: 'May all living being be well and happy' (321). Buddhism as a discourse of authenticity can thus be seen as nestled within at least two dimensions that

\footnotetext{
${ }^{7}$ Bandaranaike for instance authored an overtly Gandhain socio-economic tract entitled the "The Spinning Wheel and The Paddy Field" in the 1930s, though this "Gandhain" phase in Bandaranaike did not last long. In fact, soon afterwards it was a kind of Nehruvian policy, with modernization at its heart that Bandaranaike adopted.
} 
connect it to a larger worldly reality. At one level for Bandaranaike is the attraction of Buddhism as a discourse that resonates with modernity but at another is its transcendental and ecumenical appeal, which might appear naïve, idealistic and even disingenuous coming from a politician who played a key role in the post-independence politicisation of ethnicity and religion. But what it shows is how for figures like Bandaranaike who were comparativist thinkers, in the sense that Benedict Anderson describes it in Spectres of Comparison, the local and the global are always enmeshed. For such thinkers, keenly aware of the nation as part of a larger world system, national questions are always enmeshed within this larger reality and they make sense of their self and national identity almost by a default comparison to a larger cosmopolitan global culture.

\section{Gunadasa Amarasekara: Setting Authenticity in Stone}

Gunadasa Amarasekara and Nalin de Silva are the two intellectual architects of the influential Jathika Chintanaya movement. As a movement explicitly concerned with the place of the indigenous in the contemporary political and cultural landscape, Jathika Chintanaya inevitably confronts the problem of authenticity. The engagement with the problem of authenticity is more pronounced in Amarasekara than in de Silva. In much of his writing, both fictional and non-fictional, he revisits the legacies of Dharmapala and Bandaranaike. Buddhism and the village are also central to Amarasekara's project of locating an authentic modern Sinhala identity. However, while in his earlier writing the emphasis is on exploring Sinhala modernity in dialogue with other global discourses, in his later writing the focus narrows to an exclusively nativist position. The decolonizing discourse of the earlier Amarasekara which resembles in some ways Dharamapala's and Bandaranaike's quest for a unique Sinhala identity within a global frame gives way to one that is radically selfreferential and antagonistic towards many things perceived as western. This can potentially be understood in terms of the threat posed by Tamil nationalism to Sinhala identity and the perceived western sympathy for this nationalist cause. ${ }^{8}$

Anagarika Dharmapala Māksvādida? [Is Anagarika Dharmapala Marxist?] published in 1980 is a polemical essay which seeks primarily to explore the possibility of a Buddhist-Marxist synthesis as an ideological basis for Sinhala society. Central to Amarasekara's argument in this text is factually establishing that a transcendental Sinhala cultural essence has survived the colonial experience and that this essence can form the basis for a modern socio-political project. Amarasekara adopts a defensive stance from the outset and argues that Sri Lankan socio-political commentators have repeatedly failed to understand the significance of Dharmapala and the importance of 1956 as a politico-cultural event. He argues that Dharmapala was able to tap into a rural subaltern Sinhala Buddhist consciousness and that it is the same ideological force that emerges in 1956 after a hiatus of almost half a century because Dharmapala's project was hijacked by comprador interests. In making this argument he seeks to displace the historiography of G.C. Mendis and others who, according to Amarasekara, fail to recognize a powerful Sinhala Buddhist ideological imaginary that continues uninterrupted from pre-colonial, through colonial to post-colonial times.

The criticisms that Amarasekara mounts in the course of this essay are visible in contemporary Sinhala nationalist discourse as well. He argues that a Colombo-centric, westernized comprador elite have controlled policymaking in post-independence Sri Lanka and that their project is aided by a similarly westernized academia whose rationalist orientation prevents them from recognizing the political relevance of Sinhala Buddhist consciousness. Bandaranaike is cited as an exception in this trend and Dharmapala is read highly selectively, defending the latter's often condescending and dismissive attitude

\footnotetext{
8 See Dewasiri 2010 for more on the insecurities of Jathika Chintanaya intellectuals vis-a-vis the "West" due to the changing political climate in the 1980s and Sri Lanka's isolation within the global community in the immediate aftermath of the 1983 ethnic riots.
} 
towards villagers:

If one reads Dharmapala's writing uncritically it is not surprising that someone would form the impression that he was a religious zealot. Yet we must remember that this zealotry was something Dharmapala deliberately invokes. These articles called 'facts people should know' were written for uneducated rural Buddhists in a manner they would understand.

(Amarasekara: 17) ${ }^{9}$

Another crucial aspect to Amarasekara's project here is to argue that Buddhism has had and can have a socio-political function. He critiques western rationalist readings of Buddhism as an abstract philosophical discourse and argues for its historicisation. However, here again Amarasekara is selective in citing western scholarship that is supportive of his view of a pre-colonial Asokan-Buddhist political structure which is seen to have prevailed uninterrupted till the advent of European colonialism. Two of his main targets here are the disciplines of anthropology and sociology who are shown to have misinterpreted Buddhism and Sinhala culture in general. ${ }^{10}$ However, Amarasekara does acknowledge that a Buddhist form of governance cannot be simply actualized in modern Sri Lanka and that it needs to be melded with Marxist discourse to provide it with a critical vantage capable of dealing with a modern class-based society. Despite the polemical tone of the piece and its generally dismissive attitude towards scholarship that is considered "western", Amarasekara's thinking, at this point, is arguably consonant with decolonization and post-colonial discourse in general, which seeks some form of compromise between East and West rather than a position that is completely oppositional to the putatively "western". But this is a position that rapidly changes in the post- 83 socio-historical context.

Sketched below is Amarasekara's fictional treatment of the quest for Sinhala Buddhist authenticity in two texts. The first text Up the Ladder is a Bildungsroman that traces the life of a middle-class rural Sinhala boy Piyadasa whose journey from the village to the university and to life as a journalist in Colombo makes him radically question his Sinhala Buddhist ethos only to ultimately realize that he has been wrong all along and to achieve a kind of reintegration with his socio-cultural ethos. ${ }^{11}$ The university is the first location which exposes Piyadasa to a critical discourse on Sinhala culture. Through Piyadasa's experiences at university Amarasekara's narrative makes ironic reference to anthropologists such as Gananath Obeyesekere and his views on Protestant Buddhism and also to locally based scholars who are shown to be slavish followers of his ideas in order to suggest that modern middle class Sinhala culture is heavily influenced by Victorian ideology. Piyadasa, however, is drawn towards these ideas though at the same time we as readers are aware that this is because Piyadasa is facing a personal crisis in the form of unrequited love and poor performance at the final exams. Coincidental with these events, Ediriweera Sarachchandra, who appears as a character in the novel, introduces Piyadasa to a novel by an anonymous author which Piyadasa feels speaks directly to his predicament.

Piyadasa finished reading the novel I was Reborn given to him by Sarachchandra in one night. Finishing the novel Piyadasa felt, like the main protagonist in it, that he had ended the life he had led so far and was reborn. He felt as if the novel had been written especially for him, looking

\footnotetext{
${ }^{9}$ All translations of Amarasekara's work, unless otherwise stated, are mine.

10 One of Amarasekara's main targets here is Gananath Obeysekere and his views on how Victorian values impacted the reconfiguration of Sri Lankan Buddhist practice and Sinhala identity in the 19th century, which Obeysekere terms "Protestant Buddhism".

${ }^{11}$ Up the Ladder is part of a series of novels by Amarasekara which look at the evolution of middle class Sinhala identity. Due to space constraints only one novel is explored here though many of the novels in the series share broadly similar thematic concerns. The other novels in this sequence are: Gamanaka Mula, Gam Dorin Eliyata, Ini Mage Ihalata, Wankagiriyaka, Yali Maga Wetha, Duru Rataka Dukata Kiriyaka and Gamanaka Meda.
} 
at his inner consciousness, identifying the sickness that ailed it. ... Ranatunga's character [the main protagonist of the novel] was none other than his own.... A few days later Piyadasa went in search of Sarachchandra with great joy.

"This is an incredible work. This has revealed the consciousness of our entire middle class. This compares with the work of Lawrence and Dostoevsky...," said Piyadasa hardly pausing for breath.

"Then my judgment was correct. My judgment is rarely wrong...." [ said Saratchandra]

"What do you think of the view that Ranatunga's mind is formed by Theravada Buddhist and Victorian attitudes? I discussed this today with Dr Senaratne. He of course agrees completely. What are your thoughts?" [said Saratchandra]

"This novel proves that theory with valid evidence. I did not give it much thought when Dr Senaratne spoke about it that day. But after this novel I don't think anybody can refuse to accept it...." [replied Piyadasa]

(Amarasekara: 89)

This text is none other than the novel Yali Upannemi published by Amarasekara himself in 1962, which was hailed by Saratchandra but criticized by Martin Wickremasinghe for failing to understand the Sinhala Buddhist consciousness. (Dissanayake: 68-69) Its invocation here can be understood as a self-condemnation of an earlier naïve self and a form of public recantation. To return to the story, Piyadasa at this point is convinced that there is something radically and fundamentally wrong with Sinhala Buddhist identity and this in turn becomes the inspiration for him when he becomes a journalist in Colombo and works for an English newspaper reviewing Sinhala literature for the English press in what is shown to be a kind of native-informant role. The life Piyadasa leads in Colombo is seen as one of dissipation (alcohol and sex being the predictable vices) and one that distances him from his responsibilities and sensitivity towards his familial life in the village, which includes an unmarried sister and an unambitious elder brother.

The village however intervenes in the form of Balamahattaya (who is set up as a foil to Piyadasa from the beginning of the story; in contrast to Piyadasa, Balamahattaya is uneducated and an organic sort of individual who has not lost touch with his traditional ethos). Balamahattaya on his visit speaks to Piyadasa of his own heavy familial responsibilities which also includes an unmarried sister and his struggles to find her a dowry. In a rather contrived scene, Piyadasa recalls a letter sent to him by Martin Wickremasinghe in which Wickremasinghe critiques the main protagonist in Yali Upannemi, who is depicted as a selfish brother preventing the marriage of his sister so that she has to take care of him, as a misrepresentation because Sinhala society is better characterized by selfless exemplar figures. ${ }^{12}$ Reading the letter Piyadasa realizes that in Balamahattaya he has a real-life example of the selflessness Wickramsinghe speaks of and also realizes that his critique of middle class Sinhala Buddhist culture is unfounded. This denouement to the narrative implies that it is Piyadasa's exposure to education, and specifically a western form of education, that has alienated him from his traditional ethos.

If in Up the Ladder Amarasekara encounters a crisis engendered by the displacement of Sinhala identity outwards into an urban/modern context from its supposed rural origins, the next two texts push it back into its rural fold. In Gal Pilimaya Saha Bol Pilimaya [The Stone Statue and the Hollow Statue] (1987) and its sequel Pilima Lowai Piyevi Lowai [The World of Statues and the World of Reality] (2001), the protagonist is an educated peasant boy,

\footnotetext{
12 This, too, according to Dissanayake's account of Amarasekara's early career as a novelist, is based on a real incident where Wickramasinghe wrote to Amarasekara criticizing his depiction of Sinhala life in Yali Upannemi.
} 
Wimalasena, who also faces a moral-social crisis similar to that of Piyadasa but is less prone to Piyadasa's kind of self-doubt. Set during the time of the second JVP uprising of the 198789 period, the story chronicles a general ethico-moral crisis in society where the real can no longer be distinguished from the unreal due to political appropriation and exploitation of iconic elements of traditional culture. The main dramatic crisis of the story is precipitated when a hollow replica of an ancient stone statue is dumped alongside its original stone counterpart in Wimalasena's village. Soon all villagers except Wimalasena's father, Upalis, who is also the curator of the stone statue (a Balamahattaya type character with an organic foothold on tradition), begin worshipping the fake statue. The new statue is believed to harbour miraculous qualities and people who earlier venerated and sought assistance from the stone statue switch loyalties much to the frustration of Wimalasena's father. The problem becomes acute when the replica is painted gold by a local politician and a major public event is held where even important Buddhist monks endorse it. Simultaneously Upalis encounters a crisis in faith when he loses his cattle and no amount of searching or praying to the stone statue produces results while soon after his wife lights a lamp at the replica the cattle turn up.

While these events unfold a parallel storyline shows Wimalasena and a friend attending JVP classes in the village but Wimalasena, an unusually intelligent and sensitive child, is skeptical whether the type of righteous society that the JVP seeks can only be achieved within a Marxist/communist framework. The JVP teacher's argument that the idea of a righteous society based on Buddhist principles (which refers to how dharmishta samajaya was sloganized by the then President J.R. Jayawardene) has been rendered useless by its cotemporary political exploitation (for which the conflict between the two statues is an obvious analogue) is questioned by Wimalasena. He believes the real can be distinguished from the unreal though unsure as to how the idea of a righteous society based on Buddhism can be actualized in contemporary Sri Lankan society. The two storylines converge when Wimalasena witnesses his father's dilemma and confides in his friend who, more given to action, decides to blow up the hollow statue and dies during the explosion.

The sequel picks up the story where Wimalasena, distraught from the death of his friend, is suffering from psychosomatic shock (no one else knows that Wimalasena's friend blew up the statue and his body is never recovered). Upalis tries various folk remedies, western medicine and psychiatric consultations to cure his son but nothing works. He then learns of another replica statue in a different location which is also said to possess similar miraculous powers to the blown up statue. The family makes the journey to the remote location and on their first night there Wimalasena encounters his friend's ghost, in a dream-like sequence, who explains that blowing up the statue was a mistake. He argues with Wimalasena that people instinctually know the fake from the real and that such empty imitations have short currency and that the tradition and ethos represented by the stone statue is an intrinsic part of Sinhala society. He further suggests that discourses such as Marxism represented by the JVP are unnecessary and that all that is necessary for a modern socio-political project is available within the tradition signified by the stone statue. Following this encounter Wimalasena recovers and returns to the village but still has some doubts about his friend's claims which are dispelled by a school teacher whose advice prompts the following reflections - "Don't the ideas Dharmapala expressed about our rural society delineate the nature of this body of dharma that supported our society? Isn't Martin Wickramasinghe also attempting to portray this body of dharma we have inherited through his ideas on rural Sinhala Buddhist culture?" (Amarasekara: 111). Based on these reflections Wimalasena decides to write an article which is predictably titled, "From the world of statues to the world of reality." Towards the end of the story the teacher articulates a confident teleology of Sinhala nationalism which places Wimalasena's generation as its moment of true arrival: 
The generation that was there when this country received independence did not even know there was such a [Sinhala Buddhist] cultural current. The subsequent generation - the generation of ' 56 -realised dimly that there was something. My generation who came after that saw it better than them. I have a strong belief that your generation will see this completely."

"I think you are right sir. At least my generation knows what the stone statue is and what the hollow statue is"

(Amarasekara: 113)

What this sequel to the original story about the statue and its replica does, if somewhat crudely, is to negate the anxiety and confusion about authenticity in the first story and to assert its existence and validity. Read in tandem with $U p$ the Ladder these two short stories provide a counter narrative to the slippery nature of Sinhala Buddhist identity in middle class consciousness by locating it in the village and among the peasantry. Ironically though, the text itself attests to the tenuous nature of the cultural imaginary it seeks to posit. Upalis, the single subaltern individual within whom a traditional imaginary is shown to be preserved intact, is also portrayed as uneducated, illiterate and unable to translate it into agential action beyond his intrinsic belief grounded in mytho-historical superstition. The rest of the subaltern villagers, largely presented as a group lacking individuality, are shown to be susceptible to deception. It is in this context that Wimalasena becomes the crucial agent who can recognise the importance of this imaginary and move towards actualising it. Yet Wimalasena, though presented as a subaltern village boy, is someone who does not have the same intrinsic connection to tradition that his father has. Thus, through the events of the narrative as a whole, and specifically through the agency of the school teacher, he is made to gain this knowledge. ${ }^{13}$ What the development of nationalist consciousness in Wimalasena demonstrates is the multiple displacements through which this idea of tradition is mediated. The discourse of authenticity that this paper has been exploring so far in Dharmapala, Bandaranaike and Amarasekara is contingent and inconsistent. Wimalasena's character which attempts to encode and exemplify authenticity ironically becomes an expression of this inconsistency. Authenticity did not mean the same thing to each of these individuals. It is a discourse informed by the here and the now though its own gaze is firmly set on the past. One constant that does emerge though is how the discourse of authenticity imprisons the imagination within the thematic of anti-colonial thought in positing an irreducible East-West binary and the search for an authentic essence-a search for origins rather than contingent and partial beginnings. ${ }^{14}$

\section{A Coda to the Discussion}

Perhaps the historical irony here is that in the present moment that we inhabit Wimalasena's teacher's prophecy has become a tragically self-fulfilling one. With the election of the current government and the bloody conclusion to the War in 2009, the Sinhala south of the country appears ideologically and politically unified as never before, forming a seemingly homogenous bloc. Sinhala nationalism appears luridly ascendant as the shrill chorus of groups like Bodu Bala Sena and Ravana Balaya suggests. But ironically this moment in which Sinhala nationalism appears to have reached its apex is also a moment of great incivility. Where one might ask are the ethics that are so central to Wimalasena's nascent

\footnotetext{
${ }^{13}$ School teachers have been important vectors of Sinhala nationalist thinking. Jonathan Spencer's field work in a remote village in the Sabaragamuwa province in the 80 's has explored the role teachers play in disseminating Sinhala nationalist discourse.

14 The dichotomy between origins and beginnings is one I draw from the work of Edward Said. For Said, origins signify an authoritarian and essentialist understanding of the past while beginnings suggest something more partial, openended and contingent. (Said 1975: 43)
} 
nationalist consciousness? Even if Sinhala nationalism at best paid scant attention to minorities or at worst violently excluded or suppressed them, Amarasekara's writing specifically, and the Jathika Chintanaya project in general, was insistently focused on defining an 'ethical' Sinhala society and at least in its early phases informed by a socialist value system. But today what we have is a rainbow coalition of Sinhala forces, of which Amarasekara's Jathika Chintanaya is a powerful element, propping up a nakedly neo-liberal regime. It is here that the kind of analysis carried out in this paper may provide us with a degree of critical purchase. Sinhala nationalism, like its Tamil counterpart, though majoritarian in its imagination and exclusivist in operation, is not a monolithic whole. Thus, understanding these differences and the nuances of the discourses we seek to contest is important. Critically engaging with Sinhala nationalism's historical imagination and its ideology in such a context is a necessary, but not sufficient, condition in attempting to imagine alternatives to the postcolonial predicament of Sri Lanka.

\section{References}

Amarasekara, Gunadasa. Anagarika Dharmapala Māksvādida? [Is Anagarika Dharmapala Marxist?]. Kaluthara, Sri Lanka: Sampath Publishing House. 1980. Print

---. Gal Pilimiya Saha Bol Pilimiya Samaga Pilima Lowai Piyevi Lowai [The Stone Statue and the Hollow Statue and The World of Statues and the World of Reality]. Boralesgamuwa, Sri Lanka: Visidunu Publishers. 2001. Print

Anderson, Benedict. Imagined Communities: Reflections on the Origin and Spread of Nationalism. London: Verso. 1991 [1983]. Print

---. The Spectre of Comparison: Politics, Culture and the Nation. London: Verso. 1998. Print

---. "The Spectre of Comparisons". Arts and Sciences Newsletter 20 (2). 1998. Web

Bandaranaike, S.W.R.D. Towards a New Era: Selected Speeches of S.W.R.D. Bandaranaike. Colombo: The Department of Information. 1961. Print

---. Speeches and Writings. Colombo, Sri Lanka: Information Division of the Department of Broadcasting and Information. 1963. Print

Bangstad, Sindre. "Contesting Secularism/s: Secularism and Islam in The Work of Talal Asad," Anthropological Theory 9: 188-208. 2009. Web

Chatterjee, Partha. Nationalist Thought and the Colonial world: A Derivative Discourse? Princeton, New Jersey: Princeton University Press. 1986. Print

---The Nation and its Fragments: Colonial and Postcolonial Histories. Princeton, N.J.: Princeton University Press. 1993. Print.

Dewasiri, Nirmal Ranjith. "Mainstreaming Radical Politics in Sri Lanka: The Case of JVP Post-1997". PCD Journal, II(1): 69-94. 2010. Web

---. "History after the War: Historical Consciousness in the Collective Sinhala-Buddhist Psyche in Post-war Sri Lanka". ICES Research Paper. Colombo, Sri Lanka: International Centre for Ethnic Studies. 2013. Print

Dissanayake, Wimal. Enabling Traditions: Four Sinhala Cultural Intellectuals. Boralesgamuwa, Sri Lanka: Visidunu Publishers. 2005. Print

Gellner, Ernest. Nations and Nationalism. Ithaca, N.Y.: Cornell University Press. 1983. Print

Guha, Ranajit. “A Conquest Foretold.” Social Text 54 (Spring): 85-99. 1998. Web

Guruge, Ananda (ed.). Return to Righteousness: A Collection of Speeches, Essays and Letters of the Anagarika Dharmapala. Colombo: Ministry of Cultural Affairs and Information. 1991 [1965]. Print

Hobsbawm, Eric and Terrence Ranger. The Invention of Tradition. Cambridge: Cambridge University Press. 1983. Print 
Lopez, Donald S (ed.). The Curators of the Buddha: The Study of Buddhism under Colonialism. Chicago Illinois: The University of Chicago Press. 1995. Print

Manor, James. The Expedient Utopian: Bandaranaike and Ceylon. Cambridge: Cambridge University Press. 1989. Print

Moore, Mick. The State and Peasant Politics in Sri Lanka. Cambridge, U.K.: Cambridge University Press. 1985. Print.

---."The Ideological History of the Sri Lankan 'Peasantry'”. In Agrarian Change in Sri Lanka, ed., James Brow and Joe Weeramunda. New Delhi: Sage. 1992. Print

McMahan, David L. "Modernity and the Early Discourse of Scientific Buddhism". Journal of the American Academy of Religion 72 (4): 897-933. 2004. 2004. Web

Mufti, Aamir. "The Aura of Authenticity." Social Text 64 (18): 87-103. 2000. Web

Nissan, Elizabeth and R. L. Stirrat. "The Generation of Communal Identities." In Sri Lanka: History and the roots of Conflict, ed., Jonathan Spencer. London: Routledge. 19-44. 1990. Print

Obeyesekere, Gananath. "Personal Identity and Cultural Crisis: The Case of Anagarika Dharmapala of Sri Lanka." In The Biographical Process, ed., Frank Reynolds and Donald Capps. The Hague: Mouton and Company. 1976. Print

Rambukwella, Harshana. (forthcoming). "Postcolonial nativism: Exploring the Post-secularist Critique of History on Sri Lanka". boundary 2: an international journal of literature and culture

Roberts, Michael. "For Humanity. For the Sinhalese. Dharmapala as Crusading Bosat". Journal of Asian Studies: 56(4): 1006-1032. 1997. Web

Rogers, John D. "Historical Images in the British Period". In Sri Lanka: History and the Roots of Conflict, ed., Jonathan Spencer. London: Routledge. 87-106. 1990. Print

Said, Edward. Beginnings, Intention and Method. New York: Basic Books. 1975. Print

Spencer, Jonathan. "Representations of the Rural: A View from Sabaragamuwa." In Agrarian Change in Sri Lanka, ed., James Brow and Joe Weeramunda. New Delhi: Sage. 1992. Print

Wickramasinghe, Nira. "Producing the Present: History as Heritage in Post-war Patriotic Sri Lanka." ICES Research Paper 2. Colombo, Sri Lanka: International Centre for Ethnic Studies. 2012. Print 